\title{
REVITALISASI PANCASILA DAN BELA NEGARA DALAM MENGHADAPI TANTANGAN GLOBAL MELALUI PEMBELAJARAN BERBASIS MULTIKULTURAL
}

\author{
Satrijo Budiwibowo*
}

\begin{abstract}
Abstrak
$\mathrm{P}$ ancasila sering dilihat sebagai idiologi yang berhadapan dengan "ideologi global," seperti kapitalisme dan liberalisme. Pancasila yang dibangun adalah untuk kesejahteraan bersama dan keadilan sosial bagi seluruh rakyat Indonesia. Disisi lain kita hidup dalam globalisasi yang sarat dengan hukum dan kaidah kapitalisme, pasar bebas dan terbuka. Kita harus tetap kokoh dan kuat pada pendirian, bahwa semuanya itu tetap kita abdikan untuk kesejahteraan bersama, untuk keadilan sosial. Bangsa yang cerdas dalam era globalisasi, bukan bangsa yang terus mengeluh, menyerah, dan marah, tetapi bangsa yang mampu mengalirkan sumber-sumber kesejahteraan yang tersedia di arena global itu. Teknologi, modal, atau informasi, semua kita gunakan dengan baik guna meningkatkan kesejahteraan dan kepentingan kita. Jangan mau jadi orang yang kalah. Mari kita menjadi pemenang dalam globalisasi ini.

Pendahuluan Globalisasi merupakan era perubahan-perubahan yang cepat yang mengandung hal-hal yang positif, namun juga membawa segi-segi negatif bagi bangsa Indonesia. Bangsa Indonesia harus pandai-pandai menangkap dan memanfaatkan peluang dari segi-segi positifnya dan tetap berdiri pada nilai-nilai yang telah diikrarkan, dibela, dan dijunjung tinggi. Menghadapi globalisasi, bangsa Indonesia harus dapat tegak dengan memiliki kedaulatan di bidang politik, kemandirian bidang ekonomi, berkepribadian dalam kebudayaan, dan memiliki daya lenting yang kuat dalam ketahanan nasional. Lebih dari itu, harus tetap memperkokoh jati diri sebagai Pancasilais yang menjunjung tinggi UndangUndang Dasar Negara Republik Indonesia Tahun 1945 dan memperkokoh tegaknya Negara Kesatuan Republik Indonesia

Setiap warga negara wajib mempertahankan negaranya supaya kelangsungan hidup bangsanya tetap terpelihara. Untuk mempertahankan negara sangat ditentukan oleh sikap dan perilaku setiap warga negaranya. Jika warga negara bersifat aktif dan peduli terhadap kemajuan bangsanya maka kelangsungan hidup bangsa akan tetap terpelihara. Sebaiknya jika warga negara tidak peduli terhadap persoalan yang dihadapi bangsanya kelangsungan hidup bangsa akan terancam dan cepat atau lambat negara akan bubar.

Multikulturalisme adalah sistem keyakinan dan perilaku yang mengakui dan menghormati kehadiran semua kelompok yang beragam dalam suatu organisasi atau masyarakat, mengakui sosial-budaya mereka yang berbeda, dan mendorong dan memungkinkan kontribusi melanjutkan mereka dalam konteks budaya inklusif yang memberdayakan semua dalam organisasi atau masyarakat. Pembelajaran multikultural adalah kebijakan dalam praktik pendidikan dalam mengakui, menerima dan menegaskan perbedaan dan persamaan manusia yang dikaitkan dengan gender, ras, dan kelas (Sleeter and Grant, 1988).
\end{abstract}

\footnotetext{
* Mahasiswa Prodi PPKn IKIP PGRI Madiun
} 
Kata kunci : Revitalisasi Pancasila, Bela Negara, Globalisasi dan Pendidikan Multikultural

\section{PENDAHULUAN}

\section{Latar Belakang}

Bangsa Indonesia merupakan bangsa yang multikultur (majemuk dan plural) serta memiliki kebhinekaan yang dipersatukan oleh kesadaran kolektif untuk hidup sebagai bangsa yang merdeka dan berdaulat. Perjuangan panjang bangsa untuk bersatu, diwarnai oleh perjuangan fisik yang panjang dari generasi pendahulu bangsa untuk merdeka. Perjuangan yang diawali dari sebuah kebangkitan nasional hingga ikrar "sumpah pemuda" bukan merupakan hal yang mudah bagi bangsa Indonesia. Para pendiri negara (founding fathers) menyepakati Pancasila, yang merupakan kristalisasi nilai-nilai luhur bangsa, sebagai pandangan hidup bangsa dan dasar negara. Sebagai pandangan hidup (filsafat) nilai-nilai Pancasila yang terkandung di dalamnya merupakan nilai-nilai luhur yang digali dari budaya bangsa dan memiliki nilai dasar (intrinsik) yang diakui secara universal dan tidak akan berubah oleh perjalanan waktu.
Sedangkan sebagai dasar negara, Pancasila merupakan ideologi, pandangan dan falsafah hidup yang harus dipedomani bangsa indonesia dalam proses penyelenggaraan kehidupan bermasyarakat, berbangsa dan bernegara dalam mewujudkan cita-cita proklamasi kemerdekaan. Seiring dengan perjalanan waktu dan sejarah bangsa, kini apa yang telah diperjuangkan para pendiri dan pendahulu bangsa tengah menghadapi berbagai ujian, baik dari dalam maupun dari luar. Globalisasi dan euphoria reformasi yang sarat dengan semangat perubahan, telah mempengaruhi pola pikir, pola sikap dan pola tindak generasi penerus bangsa dalam menyikapi berbagai permasalahan kebangsaan. Pemahaman generasi penerus bangsa terkait nilai - nilai yang terkandung dalam empat pilar kehidupan berbangsa dan bernegara (Pancasila, UUD NRI Tahun 1945, NKRI dan Sesanti Bhinneka Tunggal Ika), semakin terdegradasi dan terkikis oleh derasnya nilai - nilai baru yang tidak sesuai dengan jati diri bangsa. Ironisnya, sementara nilai - nilai baru 
ini belum sepenuhnya dipahami dan dimengerti, namun nilai - nilai lama sudah mulai ditinggalkan dan dilupakan. Tanpa disadari, generasi penerus bangsa bergerak semakin menjauh dari Pancasila sebagai jati diri bangsa yang bercirikan semangat persatuan dan kesatuan. Memahami peran Pancasila di era globalisasi, khususnya dalam konteks sebagai dasar negara, merupakan tuntutan hakiki agar setiap warga negara Indonesia memiliki pemahaman yang sama dan akhirnya memiliki persepsi dan sikap yang sama terhadap kedudukan, peranan dan fungsi Pancasila dalam kehidupan bermasyarakat, berbangsa dan bernegara. Apalagi manakala dikaji perkembangannya secara konstitusional terakhir ini dihadapkan pada situasi yang tidak kondusif sehingga kridibilitasnya menjadi diragukan, diperdebatkan, baik dalam wacana politis maupun akademis.

\section{Perumusan Masalah}

Sebagai negara dengan jumlah penduduk sekitar 250 juta jiwa dan berlatar belakang berbeda baik ras, suku, dan agama, dan kepercayaan, masyarakat Indonesia hidup dalam kebersamaan sesuai dengan semboyan negara kita "Bhinneka Tunggal Ika". Berdasarkan semboyan tersebut, keberagaman di Indonesia merupakan salah satu tonggak dalam mewujudkan persatuan dan kesatuan bangsa Indonesia, bukan sebagai pemecah belah bangsa.

Kondisi keberagaman masyarakat dan budaya, secara positif menggambarkan kekayaan potensi sebuah masyarakat yang bertipe pluralis, namun secara negatif orang merasa tidak nyaman karena tidak saling mengenal budaya orang lain. Setiap etnik atau ras cenderung mempunyai semangat dan ideologi yang etnosentris, yang menyatakan bahwa kelompoknya lebih superior daripada kelompok etnik atau ras lain (Jones, dalam Liliweri, 2003). Terjadinya tidak saling mengenal identitas budaya orang lain, bisa mendorong meningkatnya prasangka terhadap orang lain, berupa sikap antipati yang didasarkan pada kesalahan generalisasi yang diekspresikan sebagai perasaan. Prasangka juga diarahkan kepada sebuah kelompok secara keseluruhan, atau kepada seseorang hanya karena itu adalah anggota kelompok tertentu. 
Jika dilihat untuk saat ini penerapan Pancasila masih jauh dari yang diharapkan masih banyak aliranaliran atau sekte-sekte yang menyesatkan yang tidak sesuai dengan sila ke-1, masih banyak masalah sosial, antara lain mengenai keadilan. Keadilan seolah-olah tidak berlaku untuk orang-orang kalangan atas, yang dimana hal ini menimbulkan kesenjangan sosial yang cukup dalam dan masih banyak lagi hal-hal lain yang menunjukan masih kurangnya penerapan Pancasila. Jadi sebenarnya apa masalah yang menyebabkan Pancasila sulit diterapkan? Ada berbagai hal antara lain globalisasi yang terus menerus menggerus rasa nasionalisme jika tidak diatasi secepatnya, adanya anggapan bahwa Pancasila hanya sebagai simbol dan lambang bukan merupakan ideologi dan cita-cita bangsa, adanya kesalahan dalam memberikan pendidikan mengenai Pancasila di jenjeng-jenjang pendidikan yang mengakibatkan generasi sekarang acuh tak acuh pada Pancasila, selain itu adanya ketidaksesuaian nilai Pancasila ketika diterapkan karena kita mengasumsikan nilai tersebut berdasarkan asumsi pada masa lalu yang tidak relevan dengam masa sekarang, agar hal ini tidak terjadi maka diperlukan aktualisasi atau pembaharuan (mengenai asumsi/interpretasi) nilai-nilai Pancasila.

Belum teraktualisasinya nilai dasar Pancasila secara konsisten dalam tataran praksis perlu terus menerus diadakan perubahan, baik dalam arti konseptual maupun operasional. Banyak hal harus ditinjau kembali dan dikaji ulang. Beberapa mungkin perlu dirubah, beberapa lagi mungkin perlu dikembangkan lebih lanjut dan dijelaskan atau diperjelas dan beberapa lagi mungkin perlu ditinggalkan. Aktualisasi nilai Pancasila dituntut selalu mengalami pembaharuan. Hakikat pembaharuan adalah perbaikan dari dalam dan melalui sistem yang ada. Atau dengan kata lain, pembaharuan mengandaikan adanya dinamika internal dalam diri Pancasila.

Menghadapi globalisasi, bangsa Indonesia harus dapat tegak dengan memiliki kedaulatan di bidang politik, kemandirian bidang ekonomi, berkepribadian dalam kebudayaan, 
dan memiliki daya lenting yang kuat dalam ketahanan nasional. Lebih dari itu, harus tetap memperkokoh jati diri sebagai Pancasilais yang menjunjung tinggi Undang-Undang Dasar Negara Republik Indonesia Thun 1945 dan memperkokoh tegaknya Negara Kesatuan Republik Indonesia dengan ke Bhinekaan Tunggal Ika nya Nampaknya pada akhir-akhir ini kurang "greget" dalam membicarakan atau memahami dan menghayati Pancasila. Sementara itu, kadar keimanan dan ketaqwaan kepada Tuhan Yang Maha Esa masih perlu ditingkatkan. Masih ada sebagian kecil masyarakat yang bersikap dan berpandangan sempit.

Berdasarkan kondisi realitas perkembangan jaman, maka dapat dirumuskan permasalahan sebagai berikut :

a. Bagaimanakah revitalisasi kedudukan Pancasila sebagai dasar negara dalam menghadapi arus globalisasi?

b. Bagaimana Pancasila
diimplementasikan sebagai
model pendidikan karakter, bela
negara yang berbasis
multikultural?

\section{PEMBAHASAN}

\section{Revitalisasi Nilai Dasar Pancasila dan Bela Negara dalam Menghadapi Globalisasi.}

Pada dasarnya semua bangsa di dunia, memiliki latar belakang sejarah, budaya dan peradaban yang dijiwai oleh sistem nilai dan filsafat, baik nilai-nilai moral keagamaan (theisme-religious) maupun nilai non religious (sekular, atheisme). Tegasnya, setiap bangsa senantiasa menegakkan nilai-nilai peradabannya dengan dijiwai, dilandasi dan dipandu oleh nilainilai religious atau non-religious. Demikian pula halnya dengan bangsa Indonesia yang majemuk dan multikultur, kehidupan dalam bermasyarakat, berbangsa dan bernegara diwarnai oleh adanya keyakinan agama dan kepercayaan yang kuat. Disisi lain aspek sosial, budaya, politik dan ekonomi juga mewarnai kehidupan ketaanegaraan suatu bangsa. Keberadaan peninggalan candi seperti candi borobudur, prambanan, dan situs peninggalan keagamaan lainnya merupakan bukti tentang 
kehidupan bangsa Indonesia yang religius sejak dulu. Hal ini menunjukkan adanya pedoman hidup dasar bangsa Indonesia yang berkeTuhanan.

Selanjutnya, prinsip yang tertuang dalam sila kedua Pancasila, merupakan bentuk kesadaran bahwa bangsa Indonesia sejak dulu telah menjunjung nilai-nilai kemanusiaan dan keadilan sesuai budaya bangsa indonesia yang beragam. Dalam budaya bangsa, manusia senantiasa ditempatkan dan diperlakukan sesuai dengan kodrat sebagai mahluk ciptaan Tuhan. Hal ini dapat dilihat dari berbagai seni budaya bangsa yang mengagungkan manusia sesuai dengan kultur dan budaya yang beragam.

Sementara itu, menyadari keragaman dan pluralitas yang dimiliki bangsa dan belajar dari pengalaman masa penjajahan, maka persatuan bangsa Indonesia menjadi tuntunan hidup bangsa Indonesia yang majemuk. Justru dengan kemajemukan yang dimiliki, bangsa Indonesia memiliki kekayaan budaya yang sangat heterogen. Prinsip persatuan indonesia bukan berarti menghilangkan eksistensi, ciri dan identitas masing-masing suku bangsa. Eksistensi, ciri dan identitas masing-masing suku bangsa tetap terpelihara dan terjaga keberadaannya.

Sila keempat merupakan bentuk kesadaran dan pengejawantahan prinsip-prinsip kehidupan kelembagaan yang didasarkan pada perilaku kehidupan gotong-royong yang telah mengakar dalam kehidupan bangsa Indonesia sejak dulu. Sifat kegotongroyongan dan musyawarah mufakat telah menjadi pilar kehidupan dalam kehidupan bermasyarakat secara turun temurun.

$$
\text { Menyadari tantangan }
$$
sebagai bangsa yang majemuk dan pentingnya persatuan bangsa, maka prinsip-prinsip kelembagaan yang didasarkan pada musyawarah untuk mufakat merupakan tuntunan bagi bangsa Indonesia dalam menjalankan kehidupan kelembagaan negara yang menentukan masa depan bangsa yang berkeadilan. Dengan 
demikian prinsip-prinsip keadilan merupakan kristalisasi keinginan dan cita-cita bangsa untuk mewujudkan suatu masyarakat yang adil dan makmur.

\section{Penetapan Pancasila} sebagai dasar negara itu memberikan pengertian bahwa negara Indonesia adalah Negara Pancasila. Hal itu mengandung arti bahwa negara harus tunduk kepadanya, membela dan melaksanakannya dalam seluruh perundang-undangan. Mengenai hal itu, Kirdi Dipoyudo (1979:30) menjelaskan: "Negara Pancasila adalah suatu negara yang didirikan, dipertahankan dan dikembangkan dengan tujuan untuk melindungi dan mengembangkan martabat dan hak-hak azasi semua warga bangsa Indonesia (kemanusiaan yang adil dan beradab), agar masing-masing dapat hidup layak sebagai manusia, mengembangkan dirinya dan mewujudkan kesejahteraannya lahir batin selengkap mungkin, memajukan kesejahteraan umum, yaitu kesejahteraan lahir batin seluruh rakyat, dan mencerdaskan kehidupan bangsa (keadilan sosial)."

Menurut pendapat Harol H. Titus. Definisi dari ideologi adalah: Aterm used for any group of ideas concerning various political and aconomic issues and social philosophies often applied to a systematic scheme of ideas held by groups or classes, artinya suatu istilah yang digunakan untuk sekelompok cita-cita mengenai bebagai macam masalah politik ekonomi filsafat sosial yang sering dilaksanakan bagi suatu rencana yang sistematis tentang suatu cita-cita yang dijalankan oleh kelompok atau lapisan masyarakat.Bila kita terapkan rumusan ini pada Pancasila dengan definisi-definisi filsafat dapat kita simpulkan, maka Pancasila itu ialah usaha pemikiran

manusia Indonesia untuk mencari kebenaran, kemudian sampai mendekati atau menanggap sebagai suatu kesanggupan yang digenggamnya seirama dengan ruang dan waktu. Apabila Pancasila tidak menyentuh 
kehidupan nyata, tidak kita rasakan wujudnya dalam kehidupan sehari-hari, maka lambat laun kehidupannya akan kabur dan kesetiaan kita kepada Pancasila akan luntur. Mungkin Pancasila akan hanya tertinggal dalam buku-buku sejarah Indonesia. Apabila ini terjadi maka segala dosa dan noda akan melekat pada kita yang hidup di masa kini, pada generasi yang telah begitu banyak berkorban untuk menegakkan dan membela Pancasila. Padahal, seharusnya, periode reformasi yang sudah berlangsung hampir 14 tahun ini kita gunakan untuk menarik pelajaran berharga dari periode sebelumnya", selain itu juga terbukti dengan bayaknya pelnggran-pelangaran HAM yang terjadi dari zaman orde lama hingga sekarang ini. Akan tetapi di balik masalah-masalah yang yang di hadapi pancasila dalam proses imlpemntasinya pancasila bagi perkembangan hidup bangsa Indonesia masih memiliki suatu keyakinan bahwa krisis multidimensional itu dapat ditangani sehingga kehidupan masyarakat akan menjadi lebih baik. Apakah yang dasar keyakinan tersebut? Ada beberapa kenyataan yang dapat menjadi landasan bagi bangsa Indonesia dalam memperbaiki kehidupannya, seperti:

1. Adanya nilai-nilai luhur yang berakar pada pandangan hidup bangsa Indonesia;

2. Adanya kekayaan yang belum dikelola secara optimal;

3. Adanya kemauan politik untuk memberantas korupsi, kolusi, dan nepotisme (KKN).

Selain itu juga pancasila mempunyai peranan penting dalam berbagai aspek dan bidang kehidupan bangsa sebagai berikut:

1. Implementasi Pancasila dalam Bidang Politik

2. Implementasi Pancasila dalam bidang Ekonomi

3. Implementasi Pancasila dalam Bidang Sosial dan Budaya 4. Implementasi Pancasila dalam bidang Pertahanan dan Keamanan

Pada era reformasi perkembangan situasi nasional cukup memprihatinkan dengan 
banyaknya permasalahan yang muncul secara bergantian di seluruh sendi kehidupan bermasyarakat, berbangsa, dan bernegara. Dampak demokratisasi yang tidak terkendali dan tidak didasari dengan pemahaman nilai-nilai Pancasila telah memunculkan sikap individualistis yang sangat jauh berbeda dengan nilai-nilai Pancasila yang lebih mementingkan keseimbangan, kerjasama, saling menghormati, kesamaan, dan kesederajatan dalam hubungan manusia dengan manusia.

Hal ini juga dirasakan dan diungkapkan oleh mantan Presiden BJ Habibie dan Ibu Megawati dalam sambutannya di depan sidang MPR RI pada tanggal 1 Juni 2011 dalam rangka memperingati Pidato Bung Karno 1 Juni 1945. Dalam sambutannya Bapak BJ Habibie manyampaikan " .......sejak reformasi 1998, Pancasila seolaholah tenggelam dalam pusaran sejarah masa lalu yang tak lagi relevan untuk disertakan dalam dialektika reformasi. Pancasila seolah hilang dari memori kolektif bangsa. Pancasila semakin jarang diucapkan, dikutip, dan dibahas baik dalam konteks kehidupan ketatanegaraan, kebangsaan maupun kemasyarakatan. Pancasila seperti tersandar di sebuah lorong sunyi justru di tengah denyut kehidupan bangsa Indonesia yang semakin hirukpikuk dengan demokrasi dan kebebasan berpolitlk ", Ibu Megawati juga menyampaikan bahwa dalam kurun 13 tahun reformasi, menunjukkan kealpaan kita semua terhadap dokumen penting sebagai rujukan Pancasila dalam proses ketatanegaraan kita".

Ekspresi dan kegundahan kedua tokoh nasional tersebut, tentu merupakan bentuk kegelisahan yang harus dijadikan tolok ukur memudarnya pemahaman masyarakat terhadap nilai - nilai luhur Pancasila. Hingga saat ini, Pancasila masih tampak kokoh berdiri mempersatukan berbagai komponen bangsa, suku bangsa, golongan dan etnik di bawah 
NKRI. Namun, bangsa ini harus berani jujur untuk mengakui bahwa Pancasila sebagai dasar negara mulai kehilangan roh dan jiwa anak bangsanya.

Bagi generasi penerus bukan suatu hal yang mudah mempertahankan komitmen para pemuda pendahulu dan pendiri bangsa dalam memperjuangkan nilai-nilai luhur pancasila. Dinamika perkembangan lingkungan strategis, baik global, regional maupun nasional setiap jaman dan era kepemimpinan, sangat mempengaruhi tumbuh kembangnya pola pikir, pola sikap dan pola tindak generasi penerus dalam menyikapi berbagai permasalahan mendasar yang dihadapi bangsa.

Di satu sisi, trauma generasi muda terhadap sikap politik pemerintahan orde baru, telah melahirkan generasi muda era reformasi yang cenderung apatis dan tidak peduli terhadap nilai-nilai luhur yang terkandung dalam Pancasila. Sementara disisi lain, era globalisasi beserta implikasinya telah merubah persepsi ancaman terhadap eksistensi suatu negara. Ancaman bagi bangsa dan negara, tidak lagi diwujudkan dalam bentuk ancaman secara fisik, melainkan ancaman tampil dalam wujud dan bentuk ancaman yang lebih kompleks dan mencakup seluruh dimensi kehidupan nasional.

Revitalisasi Pancasila dapat dimulai dengan menjadikan Pancasila kembali sebagai public discourse, wacana publik. Dengan menjadikan Pancasila sebagai wacana publik, sekaligus dapat dilakukan reassessment, penilaian kembali atas pemaknaan Pancasila selama ini, untuk kemudian menghasilkan pemikiran dan pemaknaan baru. Dengan demikian, menjadikan Pancasila sebagai wacana publik merupakan tahap awal krusial untuk pengembangan kembali Pancasila sebagai ideologi terbuka, yang dapat dimaknai secara terus menerus, sehingga tetap relevan dalam kehidupan bangsa dan negara Indonesia.

\section{Revitalisasi Bela Negara dalam} Menghadapi Globalisasi

Bela Negara adalah sikap dan perilaku warga negara yang 
dijiwai oleh kecintaannya kepada

Negara Kesatuan Republik

Indonesia yang berdasarkan

Pancasila dan Undang-Undang

Dasar 1945 dalam menjalin

kelangsungan hidup bangsa dan negara yang seutuhnya. Dengan melaksanakan kewajiban bela bangsa tersebut, merupakan bukti dan proses bagi seluruh warga negara untuk menunjukkan kesediaan mereka dalam berbakti pada nusa dan bangsa, serta kesadaran untuk mengorbankan diri guna membela negara.

Kesadaran bela negara perlu lebih ditingkatkan atau dengan kata lain perlu dilakukan revitalisasi, karena adanya pengaruh globalisasi disegala aspek kehidupan bermasyarakat, berbangsa dan bernegara asumsinya diantaranya adalah :

a. Kesadaran untuk melestarikan kekayaan budaya, terutama kebudayaan daerah yang beraneka ragam. Sehingga hal ini bisa mencegah adanya pengakuan dari negara lain yang menyebutkan kekayaan daerah Indonesia sebagai hasil kebudayaan asli mereka.

b. Untuk para pelajar, bisa diwujudkan dengan sikap rajin belajar. Sehingga pada nantinya akan memunculkan sumber daya manusia yang cerdas serta mampu menyaring berbagai macam informasi yang berasal dari pihak asing. Dengan demikian, masyarakat tidak akan terpengaruh dengan adanya informasi yang menyesatkan dari budaya asing.

c. Adanya kepatuhan dan ketaatan pada hukum yang berlaku. Hal ini sebagai perwujudan rasa cinta tanah air dan bela bangsa. Karena dengan taat pada hukum yang berlaku akan menciptakan keamanan dan ketentraman bagi lingkungan serta mewujudkan rasa keadilan di tengah masyarakat.

d. Mencegah dan memberantas korupsi. Korupsi merupakan penyakit bangsa karena merampas hak warga negara 
lain untuk mendapatkan kesejahteraan.

Dengan

mencegah dan memberantas

korupsi, kita akan membantu

masyarakat dan bangsa

dalam meningkatkan kualitas

kehidupan.

e. Meningkatkan

kualitas

perilaku

kehidupan

beragama.

Melalui

pendidikan agama dan

kepercayaan terhadap Tuhan

Yang Maha Esa yang

dilaksanakan antar umat dan

internal umat beragama dan

kepercayaan terhadap Tuhan

YME perlu di pererat dan

ditingkatkan, sehingga dapat

mencegah perilaku-perilaku

menyimpang dari ajaran

yang sebenar-benarnya

(SARA dan Terorisme).

Setiap warga negara memiliki kewajiban yang sama dalam masalah pembelaan negara. Hal tersebut merupakan wujud kecintaan seorang warga negara pada tanah air yang sudah memberikan kehidupan padanya. Dalam pelaksaan pembelaan negara, seorang warga negara bisa melakukannya baik secara fisik maupun non fisik.

Pembelaan negara secara fisik

diantaranya dengan cara perjuangan mengangkat senjata apabila ada serangan dari negara asing terhadap kedaulatan bangsa.

Sementara, pembelaan negara secara non fisik diartikan sebagai semua usaha untuk menjaga bangsa serta kedaulatan negara melalui proses peningkatan nasionalisme. Nasionalisme adalah rangkaian kecintaan dan kesadaran dalam proses berkehidupan dalam negara dan bangsa, serta upaya untuk menumbuhkan rasa cinta pada tanah air. Selain itu, pembelaan bisa dilakukan dengan cara menumbuhkan keaktifan dalam berperan aktif untuk mewujudkan kemajuan bangsa dan negara.

Globalisasi yang didominasi oleh kemajuan ilmu pengetahuan dan teknologi informasi, telah merubah pola hubungan antar bangsa dalam berbagai .aspek. Negara seolah tanpabatas (borderless), saling tergantung (interdependency) dan 
saling terhubung (interconected)

antara satu negara dengan negara lainnya. Saat ini, tidak ada satupun negara di dunia yang mampu berdiri sendiri dalam memenuhi kebutuhan masyarakat dan warganya. Dominasi negaranegara maju terhadap negaranegara berkembang semakin menguat melalui konsep pasar bebas dalam lingkup global maupun regional.

Tantangan terbesar generasi penerus saat ini adalah kemajuan teknologi informasi yang sangat cepat. Kemajuan teknologi informasi telah merubah hubungan antar negara dan pola hubungan antar manusia. Kehadiran internet dan teknologi komunikasi ikutan lainnya, memungkinkan manusia berhubungan dan berkomunikasi setiap saat dan tanpa batas. Di satu sisi, hal ini dapat memberikan kontribusi positif bagi proses pembangunan dan peningkatan kualitas hidup masyarakat. Namun disisi lain, teknologi informasi dapat digunakan sebagai sarana melemahkan ketahanan ideologi, politik, ekonomi, sosial budaya dan pertahanan keamanan suatu negara. Hal ini telah dibuktikan dengan munculnya berbagai ketidakstabilan beberapa negara yang diakibatkan oleh pembentukan opini publik dan penyebaran dokumen-dokumen rahasia melalui situs-situs yang memanfaatkan jaringan internet.

$$
\text { Persepsi bahwa bela }
$$

negara identik dengan perang telah menjebak pemahaman bela negara sama dengan wajib militer. Bela negara tidak diwajibkan kepada seluruh warga negara dan lebih diorientasikan untuk memupuk rasa nasionalisme dan patriotisme.

Meski tidak ada ancaman peperangan, pelatihan bela negara bisa saja dilakukan oleh negara jika muncul bentukbentuk ancaman yang dinilai bisa membahayakan keamanan negara. Bentuk-bentuk ancaman tersebut bisa saja berupa kejahatan terorisme internasional dan nasional, aksi kekerasan berbau SARA, pelanggaran wilayah negara baik di darat, laut, udara, dan luar angkasa, 
gerakan separatisme, kejahatan dan gangguan lintas negara, dan perusakan lingkungan. Karena itulah rakyat bisa dilibatkan dalam negara dengan wujud ikut serta dalam menjaga keamanan lingkungan, membantu korban bencana alam, menjadi aktivis lingkungan hidup, atau mengikuti kegiatan-kegiatan yang bisa meningkatkan keterampilan diri.Dengan hak dan kewajiban yang sama, setiap orang Indonesia tanpa harus dikomando dapat berperan aktif dalam melaksanakan bela negara.

Di tengah semakin kaburnya wujud dan bentuk ancaman yang berkembang dewasa ini, kerapuhan jiwa dan semangat kebangsaan sesungguhnya merupakan potensi ancaman terbesar bagi keberlangsungan dan keutuhan bangsa. Hal ini berangkat dari pemikiran bahwa pemahaman empat pilar wawasan kebangsaan akan membangkitkan semangat dan kesadaran bela negara seluruh warga negaranya dalam menghadapi berbagai bentuk ancaman. Empat pilar wawasan kebangsaan dan kesadaran bela negara merupakan unsur soft power dalam spektrum bela negara. Lebih jauh lagi, dalam konteks sistem pertahanan negara, pemahaman empat pilar wawasan kebangsaan merupakan kekuatan moral pertahanan nir militer setiap warganegara dengan berbagai profesinya untuk berpartisipasi aktif dalam mempertahankan negara. Bela Negara biasanya selalu dikaitkan dengan militer atau militerisme, seolah-olah kewajiban dan tanggung jawab untuk membela negara hanya terletak pada Tentara Nasional Indonesia. Padahal berdasarkan Pasal 30 UUD 1945, bela negara merupakan hak dan kewajiban setiap warga negara Republik Indonesia. Bela negara adalah upaya setiap warga negara untuk mempertahankan NKRI. Sebagai warga negara sudah sepantasnya kita turut serta dalam bela negara dengan mewaspadai dan mengatasi berbagai macam ancaman, tantangan, hambatan, dan gangguan pada NKRI atau Negara Kesatuan Republik 
Indonesia seperti para pahlawan yang rela berkorban demi kedaulatan dan kesatuan NKRI. Semua potensi ancaman tersebut dapat diatasi dengan meningkatkan Ketahanan Nasional melalui berbagai cara, antara lain:

1) Pembekalan mental spiritual di kalangan masyarakat agar dapat menangkal pengaruhpengaruh budaya asing yang tidak sesuai dengan normanorma kehidupan bangsa Indonesia

2) Upaya peningkatan perasaan cinta tanah air (patriotisme) melalui pemahaman dan penghayatan (bukan sekedar penghafalan) sejarah perjuangan bangsa.

3) Pengawasan yang ketat terhadap eksploitasi sumber daya alam nasional serta terciptanya suatu pemerintahan yang bersih dan berwibawa (legitimate, bebas KKN, dan konsisten melaksanakan peraturan/undang-undang).
4) Kegiatan-kegiatan lain yang bersifat kecintaan terhadap tanah air serta menanamkan semangat juang untuk membela negara, bangsa dan tanah air serta mempertahankan Panca Sila sebagai ideologi negara dan UUD 1945 sebagai landasan berbangsa dan bernegara.

5) Untuk menghadapi potensi agresi bersenjata dari luar, meskipun kemungkinannya relatif sangat kecil, selain menggunakan unsur kekuatan TNI, tentu saja dapat menggunakan unsur Rakyat Terlatih (Ratih) sesuai dengan doktrin Sistem Pertahanan Semesta.

Dengan doktrin Ketahanan Nasional itu, diharapkan bangsa Indonesia mampu mengidentifikasi berbagai masalah nasional termasuk ancaman, gangguan, hambatan dan tantangan terhadap keamanan negara guna menentukan langkah atau tindakan untuk menghadapinya. 
3. Dimensi Pancasila dan Pendekatan Pendidikan Berbasis Multikultural

Istilah "pendidikan multikultural" (multicultural education) dapat digunakan baik pada tingkat deskriptif dan normatif, yang menggambarkan isu-isu dan masalah-masalah pendidikan berkaitan dengan masyarakat multikultural. Lebih jauh ia juga mencakup pengertian tentang pertimbangan terhadap kebijakan-kebijakan dan strategistrategi bagi pendidikan bagi peserta didik di dalam masyarakat multikultural. Dalam konteks deskriptif dan normatif ini, maka kurikulum pendidikan multikultural mestilah mencakup subyek-subyek seperti; toleransi; tema-tema tentang perbedaan ethno-kultural, dan agama; bahaya diskriminasi; penyelesaian konflik dan mediasi; HAM; demokrasi dan pluralitas; kemanusiaan universal, dan subyek-subyek lain yang relevan. Pendidikan multikultural diselenggarakan dalam upaya mengembangkan kemampuan siswa dalam memandang kehidupan dari berbagai perspektif budaya yang berbeda dengan budaya yang mereka miliki, dan bersikap positif terhadap perbedaan budaya, ras, dan etnis (Farris \& Cooper, 1994).

Disisi lain Banks berpendapat bahwa pendidikan multuikultural didefinisikan sebagai sebuah kebijakan sosial yang didasarkan pada prinsipprinsip pemeliharaan budaya dan saling memiliki rasa hormat antara seluruh kelompok budaya di dalam masyarakat. Pembelajaran multikultural pada dasarnya merupakan program pendidikan bangsa agar komunitas multikultural dapat berpartisipasi dalam mewujudkan kehidupan demokrasi yang ideal bagi bangsanya (Banks, 1993). Sementara Skeel menyatakan bahwa pendidikan multikultural adalah suatu sikap dalam memandang keunikan manusia dengan tanpa membedakan ras, budaya, jenis kelamin, seks, kondisi jasmaniah atau status ekonomi seseorang (Skeel, 1995). 
Dari pendapat para ahli diatas dapat disimpulkan bahwa pendidikan multikultural (multicultural education) merupakan strategi pendidikan yang memanfaatkan keberagaman latar belakang kebudayaan dari para peserta didik sebagai salah satu kekuatan untuk membentuk sikap multicultural. Pendidikan multikultural bukanlah kebijakan yang mengarah pada pelembagaan pendidikan dan pengajaran inklusif dan pengajaran oleh propaganda pluralisme lewat kurikulum yang berperan bagi kompetisi budaya individual.

$$
\text { Bangsa Indonesia }
$$
menyadari bahwa kemajemukan etnis/suku/bangsa, ras, sosial, budaya, dan agama, merupakan bagaian yang berbeda satu sama lain, namun demi kepentingan bersama, menuju masyarakat yang adil, makmur dan sejahtera, keberagaman tersebut menjadi penguat sehingga terintegrasi secara nasional berdasarkan filsafat dan idiologi Pancasila. Kemajemukan yang terintegrasi secara nasional menjadikan kondisi potensi nasional yang dilandasi nilai-nilai ke-Bhinneka Tunggal Ika-an sebagai landasan dan pedoman dalam mewujudkan stabilitas nasional dan ketahanan nasional diharapkan menjadi kekuatan dengan segala aspekaspek yang ada didalamnya. Untuk itulah, aktualisasi pemahaman nilai-nilai Bhinneka Tunggal Ika yang termaktub dalam Pancasila sebagai filsafat dan dasar negara perlu dipahami dan dikembangkan serta diimplementasikan dalam kehidupan sosial, karena nilainilai yang terkandung dalam keBhinneka Tunggal Ika-an mempunyai fungsi sebagai motivasi dan rambu-rambu dalam menentukan segala kebijaksanaan, keputusan, tindakan dan perbuatan dalam bermasyarakat, berbangsa dan bernegara.

Pembentukan masyarakat multi-kultural Indonesia yang sehat tidak bisa secara taken for granted atau trial and error. Sebaliknya harus diupayakan secara sistematis, programatis, 
integrated

dan

berkesinambungan, dan bahkan

perlu percepatan (akselerasi).

Salah satu strategi penting dalam

mengakselerasikannya adalah

pendidikan multi-kultural yang

diselenggarakan melalui seluruh

lembaga pendidikan, baik formal

maupun non-formal, dan bahkan

informal dalam masyarakat luas.

Kebutuhan, urgensi, dan akselerasi pendidikan multikultural telah cukup lama dirasakan cukup mendesak bagi negara-bangsa majemuk lainnya. Di beberapa negara Barat, seperti Kanada, Inggris, Amerika Serikat dan lain-lain, yang sejak usainya Perang Dunia II semakin "multikultural" karena proses migrasi penduduk luar ke negara-negara tersebut (cf Hefner, 2001:2-3), pendidikan multi-kultural menemukan momentumnya sejak dasawarsa 1970-an, setelah sebelumnya di AS misalnya dikembangkan "pendidikan interkultural". Berhadapan dengan meningkatnya "multikulturalisme" di negara-negara tersebut, maka paradigma, konsep dan praktek pendidikan "multi-kultural" semakin relevan dan timely.

Pada pihak lain, gagasan pendidikan multi-kultural merupakan sesuatu hal baru di Indonesia. Meski belakangan ini sudah mulai muncul suara-suara yang mengusulkan pendidikan multi-kultural tersebut di tanahair, tidak berkembang wacana publik tentang subyek ini. Pembahasan dan literatur mengenai subyek ini sangat terbatas. Padahal, realitas kultural dan perkembangan terakhir kondisi sosial, politik, dan budaya bangsa, khususnya sejak "era reformasi" yang penuh dengan gejolak sosial-politik dan konflik dalam berbagai level masyarakat, membuat pendidikan multi-kultural terasa semakin dibutuhkan.

\section{Multi-kulturalisme}

sebagai landasan budaya, lebih jauh lagi, terkait erat dengan pencapaian civility (keadaban) yang sangat esensial bagi demokrasi yang berkeadaban dan keadaban yang demokratis (democratic civility). Dalam upaya penumbuhan dan 
pengembangan democratic

civility, maka civil society (CS)

dan pendidikan menduduki peran sangat instrumental. Terdapat persepsi dalam masyarakat untuk secara taken for granted menerima bahwa CS selalu mendorong keadaban dan demokrasi. Padahal, terdapat kecenderungan, bahwa CS terorganisasi berdasarkan distingsi sosial, budaya, etnis, dan agama - sehingga cenderung eksklusif dan merasa paling benar sendiri; akibatnya dapat kontra-produktif tidak hanya terhadap multi-kulturalisme, tetapi juga bahkan terhadap demokrasi. Karena itu, dalam hal CS seperti ini, perlu pengembangan sikap inklusif, toleran, dan respek terhadap pluralitas. Pada saat yang sama, juga harus dikembangkan CS yang mengatasi berbagai garis demarkasi tersebut, menjadi organisasi yang melintasi batasbatas etnis, agama dan sosial, sehingga pada gilirannya dapat menjadi "social and cultural capital" yang esensial bagi pengembangan dan pemberdayaan civilitas dan demokrasi yang berkeadaban (cf. Hefner 2001:9-10).

\section{KESIMPULAN}

1. Dinamika dalam mengaktualisasikan nilai Pancasila ke dalam kehidupan bermasyarakat, berbangsa, dan benegara adalah suatu keharusan, agar Pancasila tetap selalu relevan dalam fungsinya memberikan pedoman bagi pengambilan kebijaksanaan dan pemecahan masalah dalam kehidupan berbangsa dan bernegara. Agar loyalitas warga masyarakat dan warga negara terhadap Pancasila tetap tinggi.

2. Bila kita terapkan rumusan ini pada Pancasila dengan definisidefinisi filsafat dapat kita simpulkan, maka Pancasila itu ialah usaha pemikiran manusia Indonesia untuk mencari kebenaran, kemudian sampai mendekati atau menanggap sebagai suatu kesanggupan yang digenggamnya seirama dengan ruang dan waktu. 
3. Globalisasi yang didominasi oleh kemajuan ilmu pengetahuan dan teknologi informasi, telah merubah pola hubungan antar bangsa dalam berbagai .aspek. Negara seolah tanpabatas (borderless), saling tergantung (interdependency) dan saling terhubung (interconected) antara satu negara dengan negara lainnya. Saat ini, tidak ada satupun negara di dunia yang mampu berdiri sendiri dalam memenuhi kebutuhan masyarakat dan warganya.

4. Bela negara adalah membela kepentingan nasional pada seluruh aspek kehidupan nasional. Bela negara tidak hanya berhubungan dengan kepenting-an militer semata tetapi kepentingan seluruh bangsa Indonesia.

5. Dalam pelaksaan pembelaan negara, seorang warga negara bisa melakukannya baik secara fisik maupun non fisik. Pembelaan negara secara fisik diantaranya dengan cara perjuangan mengangkat senjata apabila ada serangan dari negara asing terhadap kedaulatan bangsa. Sementara, pembelaan negara secara non fisik diartikan sebagai semua usaha untuk menjaga bangsa serta kedaulatan negara melalui proses peningkatan nasionalisme.

\section{DAFTAR PUSTAKA}

Alex Suseno, 2000 Strategi Pembudayaan Kesadaran Hak Bela Negara Tahun 20002004, Jakarta,

Banks, J.A. 1993. "Multicultural Educatian: Historical Development, Dimentions and Practrice" In Review of Research in Education, vol. 19, edited by L. DarlingHammond. Washington, D.C.: American Educational Research Association.

Farris, P.J. \& Cooper,S.M, 1994, Elementary Social Studies: a Whole language Approach. Iowa Brown\&Benchmark Publishers

M. Ali, 2006 Menuju Multikultural Global, http://www2.kompascetak, diakses pada tanggal 3 Februari 2009

Saeful Rahmat, 2008, Wacana Pendidikan Multikultural di Indonesia, http://www2.kompas-cetak, diakses pada tanggal 3 Februari 2009 
Skeel, D.J, 1995, Elementary Social Studies: Challenge for Tomarrow's World, New York: Harcourt Brace College Publishers

http://lasonearth.wordpress.com, makalah, falsafah pancasila sebagai dasar falsafah negara indonesia, Rabu $28-03-2012,17: 5$

http://www.sarjanaku.com, pancasila sebagai ideologi Negara, Rabu 28 03 2012, 09:00

http://mutualprocrastination.wordpres s.com, pancasila sebagai sumber dari segala sumber hukum Negara, Senin $20-03-2012,19: 00$

http://lubisgrafura.wordpress.com/200 7/09/10/pembelajaran-berbasismultikultural/ 